Article

\title{
Foreign Direct Investment in the Power and Energy Sector, Energy Consumption, and Economic Growth: Empirical Evidence from Pakistan
}

\author{
Rashid Latief *(D) and Lin Lefen * \\ College of Finance, Nanjing Agricultural University, Nanjing 210095, China \\ * Correspondence: 2016218005@njau.edu.cn (R.L.); lefenlinna@njau.edu.cn (L.L.)
}

Received: 8 November 2018; Accepted: 17 December 2018; Published: 2 January 2019

\begin{abstract}
Pakistan significantly contributes to the overall economy of South Asia, but, for many years, it has been facing a severe energy crisis. Despite the robust economic growth and a sharp increase in energy demand, no deliberate efforts have been made to meet the energy demand of the country. Similar to other developing countries, foreign direct investment (FDI) plays a key role in the economic development of this country. Pakistan receives FDI from many countries in various sectors of the economy. This paper aims to highlight the present situation of the power and energy sector of Pakistan (PESP), and empirically analyze the causality among the FDI in the power and energy sector, the energy consumption, and the economic growth of Pakistan for the period 1990-2017. The Johansen co-integration and Granger causality tests were employed to find the causal relationships among the variables of interest in the short-run and the long-run. The sector-wise flow of FDI reveals that the power and energy sector of Pakistan (PESP) has comparatively received a higher amount of FDI than other sectors of the economy in recent years. Furthermore, trends of energy production and energy usage reveal a substantial gap in previous years. The results confirm a positive bi-directional short-run causal relationship between economic growth and energy consumption. The results also reveal the presence of long-run causality in the equation of energy consumption. Considering the current situation of PESP, policy-makers should formulate policies to attain the minimum debt level and discourage loan-based investment. Such policies would be helpful to control the severe energy crisis and increase economic growth.
\end{abstract}

Keywords: FDI; energy consumption; economic growth; power and energy sector

\section{Introduction}

At present, investment appears to be a significant factor in the economic development of any country. Specifically, foreign direct investment (FDI) constitutes the main source of economic growth in developing countries. Over the past few decades, globalization has helped to promote strong economic integration between countries. The developing countries have changed their economic policies by pulling down hurdles in the way of foreign trade and investment. Consequently, severe competition exists among developing countries to attract FDI.

FDI is helpful for developing countries, such as Pakistan, in many ways. First, it offers capital to generate positive externalities, such as employment generation, the transfer of technology, managerial skills, productivity gains, research and development, and new ways of production, in the country. Second, it encourages domestic investors to invest in the country [1]. Currently, Pakistan lies on the radar of foreign investors globally despite different political and economic challenges. Indeed, Pakistan has adopted investment-oriented policies to create opportunities for foreign investors. 
Pakistan receives FDI from different countries around the world, such as China, the United States, Japan, Norway, the United Kingdom, Hong Kong, Saudi Arabia, and Switzerland. The target sectors for FDI include the power and energy sector, financial business, trade, construction, transport, textiles, and trade. The power and energy sector of Pakistan (PESP) is one of the major sectors that receives a higher amount of FDI. Recently, the Government of Pakistan (GOP) has announced a new power policy and offered different incentives for encouraging domestic and foreign investors to invest in the power and energy sector [2].

Energy is an essential input to economic productivity. Moreover, production growth helps to increase the energy demand as a result of an increase in energy consumption [3]. The level of energy consumption is directly linked to the overall progress of a country. Therefore, per capita energy consumption is used as a proxy to measure the socioeconomic development of a country [4]. Similar to other developing countries, the energy demand and consumption of Pakistan have consistently increased with the increase in its population. Pakistan is facing a severe energy crisis due to its intense reliance on oil and gas, de-rated capacity, circular debt, energy security and threats, and bad governance. To control the energy crisis, policies should be formulated to attain the minimum debt level and discourage loan-based investment.

To take an impartial view of FDI in the power and energy sector, it is necessary to analyze the government's policies to bring a sufficient amount of FDI into the sector and its contribution to the overall economy of the country. To the best of our knowledge, no empirical study has been conducted in the context of Pakistan to examine the flow of FDI specifically in the power and energy sector and its impact on economic growth. The aim of this paper is to analyze the causality among the FDI in the power and energy sector, the energy consumption, and the economic growth in the context of Pakistan. This paper also highlights the overall structure of the power and energy sector of Pakistan (PESP), and major constraints in the progress of this sector. Finally, this paper suggests policy implications for the progress of this sector.

The rest of the paper is organized as follows. Section 2 provides an overview of the power and energy sector of Pakistan (PESP), major constraints on this sector, and the contribution of FDI to the development of this sector. Section 3 reviews the research work completed by other researchers on the relationship between FDI, energy consumption, and economic growth. Section 4 details the data collection, empirical models, and the empirical approaches adopted. Section 5 demonstrates the empirical results of this paper. Section 6 concludes the study and sketches the policy implications.

\section{Overview of Pakistan's Power and Energy Sector}

\subsection{The Structure of Pakistan's Power and Energy Sector}

The overall structure of Pakistan's power and energy sector consists of different players from the production stage to the final usage as depicted in Figure 1. The following are the major players that are involved in the sector.

\subsubsection{Suppliers of Primary Energy}

The major suppliers of primary energy in Pakistan, such as Oil and Gas Development Company Limited (OGDL), Pakistan Petroleum Limited (PPL), and Pakistan Oilfields Limited (POL), supply crude oil to the refineries. The refineries refine the crude oil and supply it to the end consumers through oil distributors. Pakistan is heavily dependent upon oil and gas resources to meet its energy demand. Domestic oil resources are not enough to fulfill the country's energy requirement. Therefore, Pakistan imports crude oil, which satisfies about one-third of its total oil demand, from different countries, such as Saudi Arabia and Middle Eastern countries, to fulfill its energy demand [5]. 


\subsubsection{Power Generators and Power Distributors}

There are three major power generators operating in Pakistan: Generation Companies (GENCOS), Karachi Electric Supply Corporation (KESC), and Independent Power Producers (IPPs). The power is transmitted from these power generators and other projects (hydel and nuclear) to the power distributors. The power distributors supply power to the end consumers.

\subsubsection{End Consumers}

The end consumers, which consume the energy to fulfill their demand, comprise individual households, different industries, government institutes, and transporters. End consumers pay tariffs that are often subsidized by the government in the form of power and fuel subsidies. These tariffs are utilized to make payments at different phases of the energy supply chain [6].

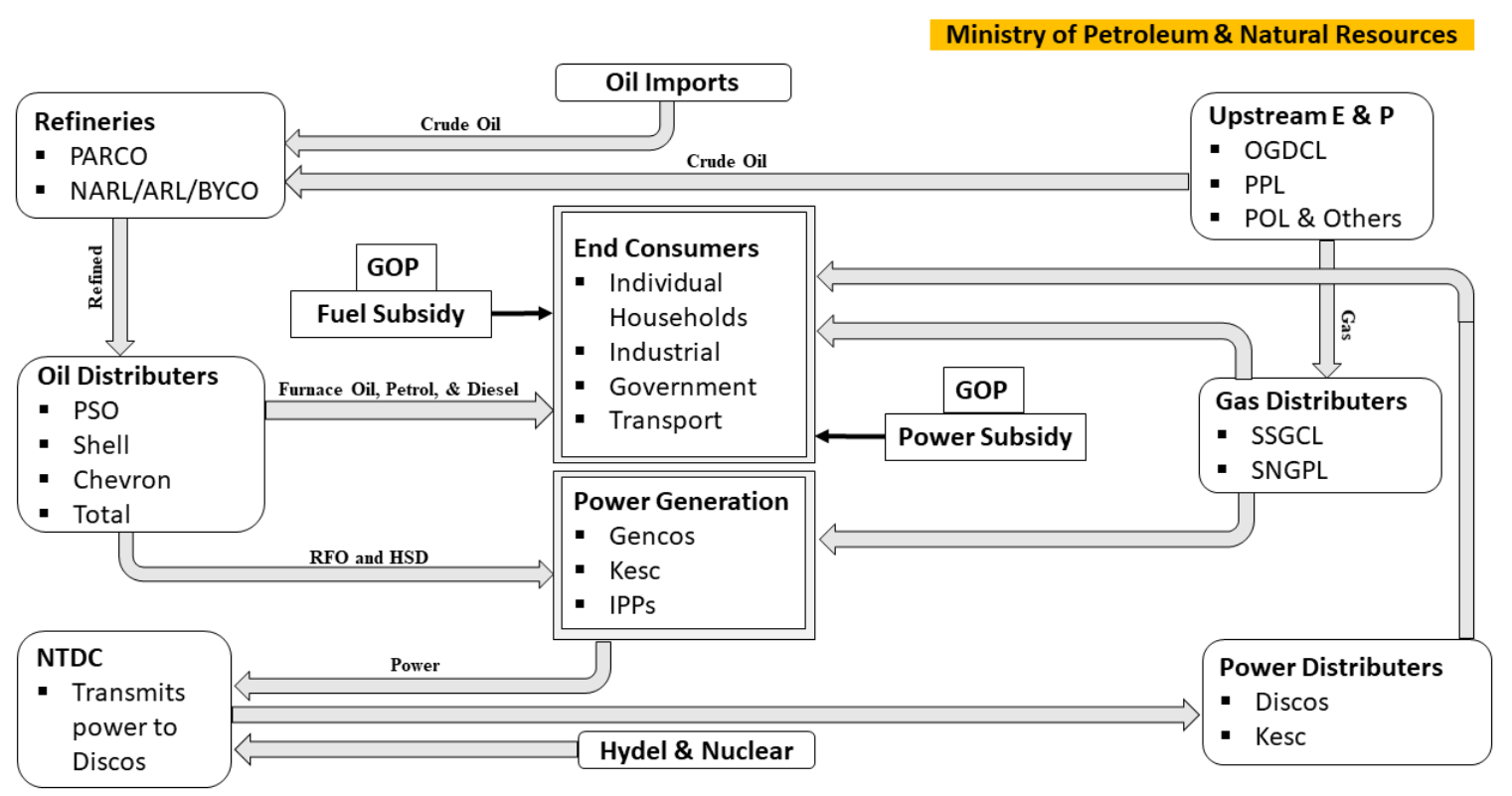

Ministry of Water \& Power

Figure 1. The structure of Pakistan's Power and Energy Sector [7].

\subsection{Major Constraints on Pakistan's Power and Energy Sector}

Pakistan has been facing a severe energy crisis for a long time. Despite the robust economic growth and a sharp increase in energy demand, no solemn efforts have been made to satisfy the energy demand in the past few decades. The following are the major constraints behind the energy crisis in the country.

\subsubsection{Intense Reliance on Oil/Gas}

Pakistan is highly dependent upon the import of fossil fuel from foreign countries. Fuel import is connected with the volatile price structure of oil in the international oil market. In highly volatile circumstances, Pakistan pays a higher cost for importing fossil fuel to meet its domestic requirement for producing energy. Pakistan spends about $60 \%$ of its foreign exchange reserves on importing fossil fuel from the international oil market. For instance, the oil prices were increased recently in the international market. The higher oil prices and the shortage of funds adversely affected the quantity demand of Pakistan for importing oil. As a result, the gap between energy demand and supply was increased [5].

Pakistan has different choices for improving the current situation of the power and energy sector. It can change its power policy by focusing on alternative energy sources, such as hydro projects, wind 
projects, and solar projects. Pakistan requires new dams to fulfill the energy requirement of the country. Although Pakistan already has a few dams, namely the Tarbela Dam, the Mangla Dam, the Mirani Dam, the Warsak Dam, and the Sabakzai Dam, these dams do not produce enough energy to fulfill the energy requirement of the country.

\subsubsection{De-Rated Capacity}

Many energy production units are installed at different places in Pakistan, but their energy producing capacity has been de-rated with the passage of time. There are different factors behind this situation, such as mismanagement, a shortage of funds, the availability of oil, and a lack of proper maintenance. For instance, the total installed capacity of PESP was 24,953 MW for generating electricity until June 2014. Although the power producers were capable of producing more electricity, as a result, Pakistan suffered severe load shedding in the subsequent years [8].

\subsubsection{Circular Debt}

Circular debt is one of the major constraints that Pakistan's power and energy sector has faced for many years. The problem of circular debt arises as the operating energy units face the issue of cash flows with their creditors and suppliers. SS Ali and S Badar [6] highlighted different reasons for the circular debt:

(1) The failure of distribution companies to collect due payments from their receivables (mainly government-owned organizations);

(2) The default of distribution companies on making payments to energy producers;

(3) The default of energy producers on making payments to oil companies for purchasing fuel; and

(4) Late payments of oil companies to oil refineries.

For instance, the figure of Pakistan's circular debt approached 977 billion rupees at the beginning of 2018, and it is the highest figure of circular debt that the PESP has yet faced. Out of the total figure of circular debt, 542.9 billion rupees were payables, while 434 billion rupees were pending in the form of loans borrowed by Power Holding Private Limited (PHPL). Looking at the receivables, billions of rupees are pending to be received by the Central Power Purchase Agency (CPPA) from different government and private organizations. This overall situation of circular debt has made the power and energy sector of Pakistan more stagnant [9].

\subsubsection{Energy Security and Threats}

Pakistan's domestic oil and gas resources are very limited. The domestic oil reserves could be depleted within the next 13 years, while the gas reserves are available for the next 16 years. Therefore, Pakistan imports oil from different countries to fulfill its domestic oil demand. This situation creates grave concerns about energy security. The main threat to energy security is from foreign routes for importing oil, because these might be disrupted at any time due to global conflicts. Moreover, the seaports might also be dysfunctional in the case of war between countries. As a result, Pakistan's entire thermal electricity production system could be adversely affected [4].

The main gas resources of Pakistan exist in the provinces of Baluchistan and Sindh. The political and security situation of these provinces could significantly affect the energy sector. In 2013, Pakistan formally inaugurated the Iran-Pakistan gas pipeline project to import gas from Iran. However, this project has not yet been completed, although it was expected to be complete in December 2017. The main reason behind it was the economic sanctions imposed by the United States on Iran. Moreover, the Government of Pakistan (GOP) has recently negotiated with Qatar and started to import LNG for fulfilling the energy requirement of the country. Conversely, the opponents of this project have filed cases in courts of law. The court decisions are still pending, and could affect the import of LNG in the country. 


\subsubsection{Bad Governance}

The power and energy sector of Pakistan (PESP) has faced bad governance for a long time. The main reason is the political influence on energy entities from the public sector. The main political parties, which govern the country, have badly damaged the administrative structure of these entities by hiring incompetent employees on a political basis. As a result of bad governance, the PESP has faced non-technical losses and the theft of gas and electricity in highly politically influenced and insecure areas of Pakistan. The problem of circular debt is also interlinked with this constraint.

\subsection{Energy Production, Import, and Consumption}

The primary energy production and energy usage have deteriorated with the passage of time in Pakistan as depicted in Figure 2. There are different factors involved in it. Examples are: the intense reliance on oil and gas, a curtailing of the demand for oil in terms of quantity, ignoring hydro projects, circular debt, insufficient funds, bad governance, and political influences. Figure 3 highlights that the net energy imports have been increasing gradually, while the commercial usage of energy has increased sharply in recent years. Pakistan, like other developing countries, imports crude oil from Arabian countries, and LNG from Qatar, to fulfill its energy requirement. Pakistan has also planned to import electricity from Kyrgyzstan and Tajikistan, and develop many energy projects under the China Pakistan Economic Corridor (CPEC) project.

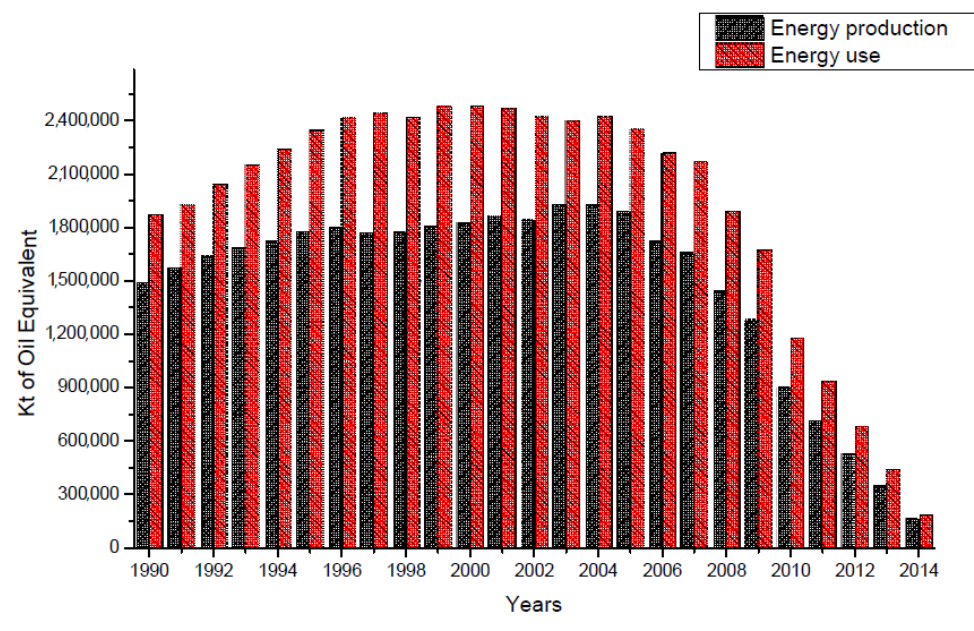

Figure 2. Trends of primary energy production and energy usage.

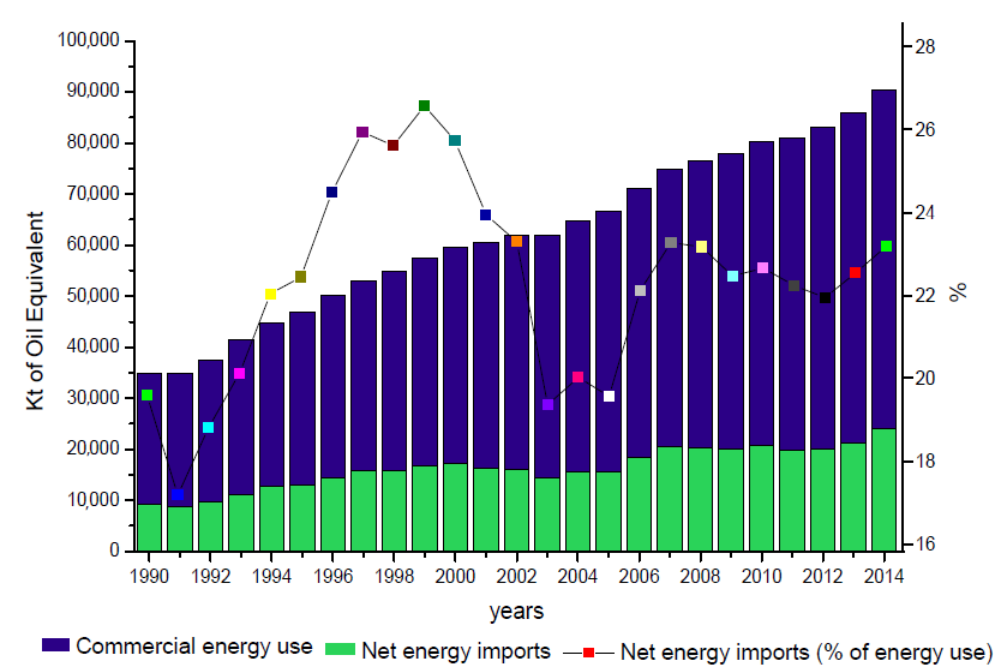

Figure 3. Trends of net energy import, net energy usage, and commercial energy usage. 


\subsection{The Role of FDI in Pakistan's Power and Energy Sector}

The energy requirements of Pakistan are inflating quickly as the population of the country has been following an increasing trend for many years. The GOP has taken steps to make sure that there is sufficient energy security to go along with the expansion in natural resources. Pakistan has hydro and coal resources, which, if exploited, could be helpful to fulfill the energy requirements of the country in the future. The latest power production policy was announced in 2015 by the government of Pakistan (GOP), in which it offered different incentives to attract domestic and foreign investors to invest in power projects. The major aims of this policy are the following: (a) To supply an adequate power production capacity with the minimum cost; (b) To boost up, and make sure of, the exploitation of domestic resources; (c) To provide a win-win situation to all key players and obtain their confidence in the process; and (d) Be accustomed to a secure environment [2].

The comparison of FDI in different sectors of Pakistan is shown in Figure 4. It highlights that the power and energy sector of Pakistan (PESP) has received a comparatively higher amount of FDI (about 35.58 percent), followed by the communication and financial business sectors ( 24.26 percent and 21.26 percent, respectively) in previous years. FDI in PESP has contributed significantly to the overall economic growth of the country over this period. The flows of FDI in the PESP and economic growth are shown in Figure 5. Both economic growth and FDI showed upward trends at the beginning of the period, while FDI continued in an upward trend until the year 1998. In the year 1998, Pakistan tested its nuclear missiles to attain atomic power at the international level. As a result, Pakistan faced different economic sanctions internationally and was confronted with the consequences in the form of a downward trend in FDI.

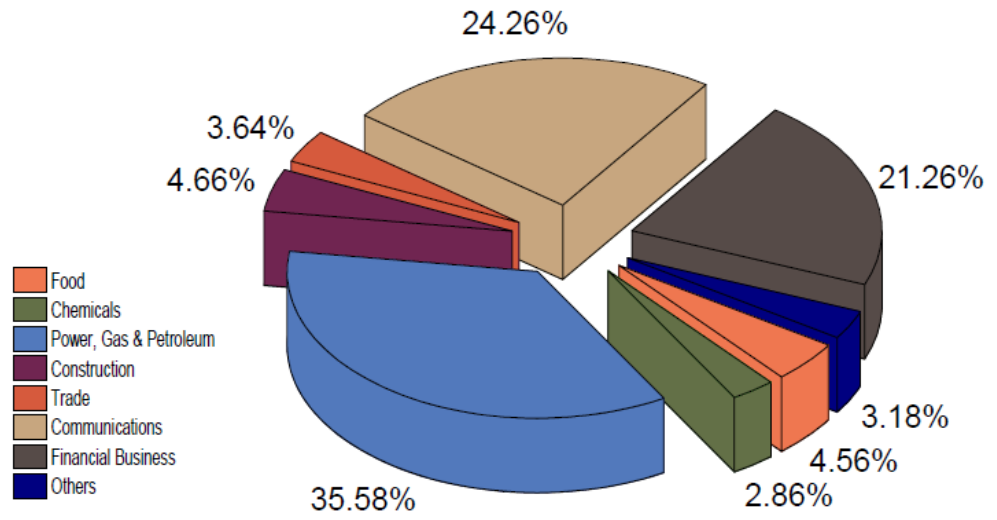

Figure 4. Sector-wise Foreign Direct Investment for the period 2001-2017.

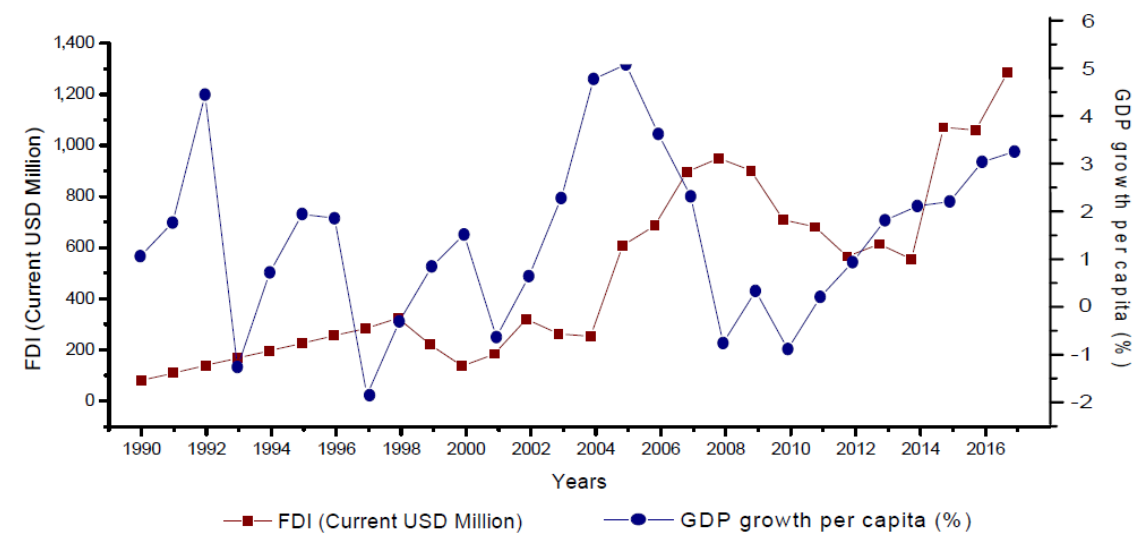

Figure 5. Trends of foreign direct investment (FDI) (Current U.S.\$) in the power and energy sector of Pakistan (PESP) and the GDP growth per capita (\%). 
The other major possible reasons for the downward trend in FDI were the political turmoil and the security situation in Pakistan. In the year 1999, Pakistan faced a severe political crisis; consequently, the military took over the civilian government based on allegations of bad governance and other political issues. After the 9/11 terrorist attacks in the United States, Pakistan participated in the war against terrorism. As a result, the security situation in Pakistan became paralyzed, and investors avoided investing in Pakistan. After a certain number of years, the relationship of Pakistan with other countries, and its political and security situation, became better. Thereafter, FDI showed an upward trend from 2005 to 2008. From the year 2009, FDI showed a mixed trend for the subsequent period. However, the economic growth of Pakistan has followed an upward trend since the year 2002.

In recent years, Pakistan has quietly succeeded in attracting foreign investors by offering tax incentives and providing a secure environment in the country. In the last five years, a number of new power projects were installed with the help of foreign investment [10]. The major projects, which were installed during the period 2014-2018, include GENCO-II, Guddu CC, Quaid-e-Azam (a solar plant), Nandipur (a thermal plant), Crest Energy, Chasnupp C-3 (nuclear), Chasnupp C-4 (nuclear), United Energy (wind), Patrind (hydel), Neelum Jehlum (hydel), Port Qasim (coal), Balloki (RLNG), and Tarbela T-4 Unit-17 (Hydel) [2]. Pakistan receives FDI from different countries, such as China, the United Kingdom, and the United States. After starting the CPEC project, the amount of Chinese investment in Pakistan has been significantly increased as compared to other countries [11].

\section{Theoretical and Literature Framework}

\subsection{Foreign Direct Investment (FDI) and Economic Growth}

The economic literature revolves around two main theories-modernization and dependency theories-to elaborate the linkage between FDI and economic growth [12]. According to modernization theory, FDI helps to increase economic growth based on the significance of capital investment for achieving growth. FDI is the main source of technology transfer from developed countries to developing countries, which provides assistance to promote the domestic industry. Usually, developing countries suffer from less developed infrastructure, political and economic instability due to insufficient resources. It is generally claimed that FDI could be helpful for the transfer of knowledge, marketing expertise, managerial skills, and different opportunities to access the market $[13,14]$.

On the other side, according to the dependency school theory advocated by D O'Hearn [15], V Bornschier [16], and C Stoneman [17], FDI inflows can show a negative relationship with economic growth in the long-run. The basic reason was that the First World countries after World War II became wealthier by mining different resources from Third World countries. The developing countries were inadequately rewarded for their natural resources, which led to continuous poverty in those countries. The theorists found that capitalism is a basic cause for labor division at a global level. As a result, FDI can create hurdles for growth and increase the income inequality, which can negatively affect economic growth in the long-run.

There could also be some other reasons for the negative linkage between FDI and economic growth. The most important reason is that foreign investment can reduce the production level of domestic firms through competition in the market. Usually, foreign firms face lower marginal costs because of a firm-specific advantage, which provides them with the opportunity to captivate demand away from domestic firms. As a result, their cost is increased and production level decreased. There is also another reason that foreign firms may not be willing to spread firm-specific knowledge to domestic firms. As a result, the production of domestic firms could lead to an adverse situation due to backward technology and less-skilled workers [18].

The debate about the relationship of FDI to economic growth has been extensively studied in the literature. However, the empirical results are varied across countries based on domestic human capital, infrastructure, and domestic policies to promote foreign investment and trade. Some studies revealed the direct linkage of FDI with economic growth, while there are also many studies in the literature 
that have highlighted the inverse linkage of FDI with economic growth. Studies that have specifically focused on FDI in the power and energy sector and its effect on economic growth are rarely available in the empirical literature. Most of the prior studies have focused on the analysis of overall FDI and its relationship to economic growth along with different exogenous variables.

The studies that focused on a single country to explore the nexus of FDI-economic growth include MA Almfraji, MK Almsafir, and Y Liu [19]; C Zhao and J Du [20]; M Belloumi [21]; F Khatun and M Ahamad [12]; Y Hao, L Zhu and M Ye [22]; JS Mah [23]; MA Fadhil and MK Almsafir [24]; C Chakraborty and P Nunnenkamp [25]; S Anwar and S Sun [26]; and CF Tang and BW Tan [27]. The studies that selected multiple countries to analyze the nexus of FDI-economic growth include P Gupta and A Singh [28]; S Iamsiraroj [29]; A Omri and B Kahouli [30]; G Agrawal [31]; D Herzer [18]; S Adams [13]; P Srinivasan, M Kalaivani, and P Ibrahim [32]; M Al-Iriani [33]; and SL Gui-Diby [34].

For example, in the case of a single country to examine the nexus of FDI-economic growth, MA Almfraji, MK Almsafir, and Y Liu [19] used time-series data for the period 1990-2010 by focusing on Qatar as a sample. Using Vector Auto-Regression (VAR) and Granger causality tests, the results of the study showed a significant effect of FDI inflows on economic growth in the long-run. C Zhao and J Du [20] used a unit root test, the vector error correction model (VECM), the Augmented-Dickey-Fuller (ADF) test, and a co-integration test, and found a non-significant causal relationship between FDI and economic growth in the context of China for the period 1985-2003.

Moreover, M Belloumi [35] applied the ARDL bounds testing technique to study the relationship among trade openness, economic growth, and FDI by using data on Tunisia for the period 1970-2008. The findings of the study highlighted that there is no significant causality between economic growth and FDI. More specifically, F Khatun and M Ahamad [12] could not find causality between FDI in the energy sector and economic growth in both the long-run and the short-run by using Granger causality tests in case of Bangladesh.

In the case of multiple countries to analyze the nexus of FDI-Economic growth, P Gupta and A Singh [28] used a panel of data on BRICS countries for the period from 1992 to 2013 . Using the ordinary least square (OLS) technique, the Johansen co-integration technique, and VECM, the results showed a causal relationship between FDI and economic growth in the context of China, Brazil, and India. Furthermore, the results also showed a short-run causal relationship between FDI and economic growth in the case of China. S Iamsiraroj [29] applied the fixed effect model and the Generalized Method of Moments (GMM) model to a sample of 124 countries for the time span 1971-2010. The findings established the direct linkage of FDI with economic growth, while economic freedom, trade openness, and labor force, as the major determinants of FDI, were found to directly increase the income growth.

Moreover, A Omri and B Kahouli [30] observed the relationship between FDI, energy consumption, and economic growth by constructing a panel dataset of 65 countries for the period 1990-2011. They divided the panel dataset more into three sub-panel datasets based on various income levels. Using simultaneous equations with GMM, the results revealed bi-directional causality between FDI and economic growth in some countries. G Agrawal [31] employed VEC Granger causality and panel co-integration, and confirmed causality between FDI and economic growth by using a panel dataset on BRICS countries for the period 1989-2012. Table 1 shows a summary of the main empirical studies about the FDI-economic growth nexus. 
Table 1. A Summary of Empirical Studies on the Foreign Direct Investment (FDI)-Economic Growth Nexus.

\begin{tabular}{|c|c|c|c|c|}
\hline Author (s) & Country & Sample Period & Analysis Technique & Findings \\
\hline \multicolumn{5}{|c|}{ Single Country Studies } \\
\hline Y Hao, L Zhu and M Ye [22] & China & 1995-2010 & $\begin{array}{l}\text { The vector error correction model (VECM), fully } \\
\text { modified ordinary least squares (FMOLS) }\end{array}$ & $\begin{array}{l}\text { Bi-directional causality exists in the } \\
\text { long-run }\end{array}$ \\
\hline JS Mah [23] & China & $1983-2011$ & Johansen co-integration test; Granger causality test & Mixed Results \\
\hline $\begin{array}{l}\text { MA Fadhil and } \\
\text { MK Almsafir [24] }\end{array}$ & Malaysia & $1975-2010$ & $\begin{array}{l}\text { Unit root tests, Johansen Co-integration test, } \\
\text { Hierarchical Multiple Regressions (HMR) }\end{array}$ & Significant positive relationship. \\
\hline $\begin{array}{l}\text { C Chakraborty and } \\
\text { P Nunnenkamp [25] }\end{array}$ & India & $1987-2000$ & Granger causality tests, Johansen co-integration. & $\begin{array}{l}\text { Bi-directional causality in the } \\
\text { manufacturing sector. }\end{array}$ \\
\hline S Anwar and S Sun [26] & Malaysia & 1970-2007 & Generalized Method of Moments (GMM) & Significant positive relationship. \\
\hline CF Tang and BW Tan [27] & Malaysia & 1972-2009 & $\begin{array}{l}\text { Unit root tests, Johansen-Juselius co-integration test, } \\
\text { Granger Causality tests, ECM }\end{array}$ & Bi-directional causality \\
\hline \multicolumn{5}{|c|}{ Multi-Country studies } \\
\hline D Herzer [18] & 44 developing countries & 1970-2005 & Heterogeneous panel co-integration techniques & $\begin{array}{l}\text { On average: a negative effect in } \\
\text { most of the countries }\end{array}$ \\
\hline S Adams [13] & Sub-Saharan African countries & $1990-2003$ & Ordinary least square (OLS) model, Fixed effect model & $\begin{array}{l}\text { Mixed results, positive results in } \\
\text { case of OLS }\end{array}$ \\
\hline $\begin{array}{l}\text { P Srinivasan, M Kalaivani } \\
\text { and P Ibrahim [32] }\end{array}$ & SAARC countries & 1970-2007 & $\begin{array}{l}\text { Johansen co-integration test, VECM, the Impulse } \\
\text { response function }\end{array}$ & $\begin{array}{l}\text { Bi-directional causality exists in all } \\
\text { selected countries except India }\end{array}$ \\
\hline M Al-Iriani [33] & $\begin{array}{l}\text { Bahrain, Kuwait, Oman, Saudi } \\
\text { Arabia, and United Arab Emirates }\end{array}$ & 1970-2004 & Granger causality test, Panel co-integration test & Bi-directional causality \\
\hline SL Gui-Diby [34] & 50 African Countries & 1980-2009 & System generalized method of moment (SYS-GMM) & $\begin{array}{l}\text { Mixed results, } 1980-1994 \text { negative, } \\
\text { 1995-2009 positive }\end{array}$ \\
\hline
\end{tabular}




\subsection{Energy Consumption and Economic Growth}

In the economics literature, the debate about the nexus of energy consumption and economic growth was initiated by J Kraft and A Kraft [36], and found the strongest evidence of a relationship between these variables by using data on the United States for the period 1947-1974. Afterward, many researchers examined causal relationships by using Granger causality and tested four hypotheses: (a) the conservation hypothesis, (b) the neutrality hypothesis, (c) the feedback hypothesis, and (d) the growth hypothesis [37].

Neoclassical economists, such as ER Berndt [38] and EF Denison [39], argued that energy is not the significant factor that causes economic growth based on the assumption that energy affects economic growth only in definite ways. On the contrary, ecological economists, such as RU Ayres and I Nair [40], proposed a model in which they highlighted energy as the main factor of production based on the Laws of Thermodynamics. Afterward, other researchers, such as CJ Cleveland, R Costanza, CA Hall, and R Kaufmann [41], also endorsed their model by finding significant evidence about the relationship between economic production and energy. Furthermore, DI Stern [42] also considered energy to be a vital factor in production.

A fairly considerable number of studies have focused on the linkage of energy consumption with economic growth in many countries. The studies that focused on a single country to analyze the relationship between these variables include I Ozturk and A Acaravci [43]; X-P Zhang and X-M Cheng [44]; N Bowden and JE Payne [45]; M Shahbaz, M Zeshan, and T Afza [46]; AS Alshehry and M Belloumi [47]; W Oh and K Lee [48]; M Belloumi [21]; G Erdal, H Erdal, and K Esengün [49]; F Karanfil [50]; W Lise and K Van Montfort [51]; K Bakhsh, S Rose, MF Ali, N Ahmad, and M Shahbaz [52]; and F Khatun and M Ahamad [12]. The studies that concentrated on multiple countries to examine the energy consumption-economic growth nexus include VC Govindaraju and CF Tang [53]; E Lau, X-H Chye, and C-K Choong [54]; RPP Pradhan [55]; N Apergis and JE Payne [56]; J Asafu-Adjaye [57]; AM Masih and R Masih [58]; S Noor and M Siddiqi [59]; C-C Lee, C-P Chang, and P-F Chen [60]; and B-N Huang, MJ Hwang, and CW Yang [61].

For example, in the case of a single country to analyze the nexus of energy consumption and economic growth, I Ozturk and A Acaravci [43] used the ARDL technique and Granger causality tests, and revealed a relationship among economic growth, employment rate, and energy consumption; however, while carbon emissions and energy consumption did not show causality with economic growth, the employment rate showed a causal relationship with economic growth in Turkey for the sample period 1968-2005. In addition, X-P Zhang and X-M Cheng [44] used a multivariate model to analyze the relationship among carbon emissions, urban population, economic growth, and energy usage by selecting China as a sample for the period 1960-2007. Using co-integration and Granger causality tests, the results highlighted the unidirectional causality between energy consumption and economic growth in the long-run.

With the same view, M Shahbaz, M Zeshan, and T Afza [46] analyzed the relationship between renewable and non-renewable energies and economic growth by selecting Pakistan as a sample for the period 1972-2011. Using ARDL and Granger causality tests, the results established a long-run causal relationship between energy consumption and economic growth. AS Alshehry and M Belloumi [47] examined the inter-relationship between economic activity, energy consumption, and energy price for Saudi Arabia by using data for the period 1971-2010. Using Johansen multivariate co-integration tests and VECM, the results indicated that there is unidirectional causality running from energy consumption to economic growth in the long-run.

In the case of multiple countries to examine the nexus of energy consumption and economic growth, VC Govindaraju and CF Tang [53] employed the co-integration technique and VECM to analyze the relationship among $\mathrm{CO}_{2}$ emissions, economic growth, and coal consumption in India and China. The results highlighted the causality among coal consumption, economic growth, and $\mathrm{CO}_{2}$ emissions in the case of China, but not in India. The results confirmed a unidirectional causal relationship between $\mathrm{CO}_{2}$ emissions and economic growth. E Lau, X-H Chye, and C-K Choong [54] 
studied the causality between energy consumption and economic growth in the context of 17 Asian countries by using a panel of data for the time duration from 1980 to 2006 . The results of the study revealed that there is a long-run equilibrium in the selected countries. Furthermore, energy consumption showed direct causality with economic growth both in the long-run and in the short-run.

In addition, RPP Pradhan [55] explored the relationship of energy consumption, electricity consumption, and oil consumption with economic growth by selecting SAARC countries as a sample for the time duration 1970-2006. Using the Johansen co-integration technique and VECM, the results of the study highlighted unidirectional and bidirectional causality among the variables across the selected countries based on the type of energy consumption. N Apergis and JE Payne [56] applied the Pedroni co-integration technique and VECM, and revealed unidirectional causality between economic growth and energy consumption by using data on six Central American states for the period 1980-2004. A summary of important empirical studies on the energy consumption-economic growth nexus is shown in Table 2. 
Table 2. A summary of Empirical Studies on the Energy Consumption (EC)-Economic Growth Nexus

\begin{tabular}{|c|c|c|c|c|}
\hline Author (s) & Country & Sample Period & Analysis Technique & Findings \\
\hline \multicolumn{5}{|c|}{ Single Country Studies } \\
\hline W Oh and K Lee [48] & Korea & 1970-1999 & Granger causality and VECM & Unidirectional causality from EC to GDP \\
\hline M Belloumi [21] & Tunisia & 1971-2004 & Granger causality and VECM & $\begin{array}{l}\text { Bi-directional causality in the long-run; } \\
\text { Unidirectional causality in the short-run }\end{array}$ \\
\hline $\begin{array}{l}\text { N Bowden and JE Payne } \\
{[45]}\end{array}$ & USA & 1949-2006 & Toda-Yamamoto & Unidirectional causality from EC to GDP \\
\hline $\begin{array}{l}\text { G Erdal, H Erdal, and K } \\
\text { Esengün [49] }\end{array}$ & Turkey & 1970-2006 & $\begin{array}{l}\text { Granger causality test, Johansen } \\
\text { co-integration test }\end{array}$ & Bi-directional causality \\
\hline F Karanfil [50] & Turkey & 1970-2005 & Granger causality test, Co-integration test & Unidirectional causality from GDP to EC \\
\hline $\begin{array}{l}\text { W Lise and K Van } \\
\text { Montfort [51] }\end{array}$ & Turkey & 1970-2003 & Co-integration test & Unidirectional causality from GDP to EC \\
\hline \multicolumn{5}{|c|}{ Multi-Country studies } \\
\hline J Asafu-Adjaye [57] & $\begin{array}{l}\text { The Philippines, Thailand, } \\
\text { India, Indonesia }\end{array}$ & $\begin{array}{l}\text { 1971-1995; } \\
1973-1995\end{array}$ & Granger causality test, Co-integration test & $\begin{array}{l}\text { Bi-directional causality in case of The } \\
\text { Philippines and Thailand; Unidirectional } \\
\text { causality in case of India and Indonesia }\end{array}$ \\
\hline $\begin{array}{l}\text { AM Masih and R Masih } \\
\text { [58] }\end{array}$ & 6 Asian countries & 1955-1990 & $\begin{array}{c}\text { Granger causality test, Co-integration } \\
\text { test-ECM }\end{array}$ & Mixed results \\
\hline $\begin{array}{l}\text { S Noor and M Siddiqi } \\
\text { [59] }\end{array}$ & 5 South Asian Countries & 1971-2006 & $\begin{array}{c}\text { Granger causality test, Co-integration } \\
\text { test-ECM }\end{array}$ & Mixed results \\
\hline $\begin{array}{l}\text { C-C Lee, C-P Chang, } \\
\text { and P-F Chen [60] }\end{array}$ & 22 OECD countries & 1960-2001 & Panel Co-integration-Panel VEC & Overall, Bidirectional causality \\
\hline $\begin{array}{l}\text { B-N Huang, MJ Hwang, } \\
\text { and CW Yang [61] }\end{array}$ & $\begin{array}{l}82 \text { countries with different } \\
\text { income levels }\end{array}$ & 1972-2002 & GMM, Vector Auto-Regression (VAR) model & $\begin{array}{l}\text { Mixed results; Unilateral causality in } \\
\text { middle and high-income countries }\end{array}$ \\
\hline
\end{tabular}




\section{Materials and Methods}

This section contains the empirical models and techniques to find causality among the FDI in the power and energy sector, the energy consumption, and the economic growth of Pakistan in both the long-run and the short-run.

\subsection{Empirical Approach and Data Collection}

The Vector Error Correction Model (VECM) and Vector Auto-Regression (VAR) are the two prominent empirical models that are usually employed to identify Granger causality among variables in such studies. VAR can be employed if the variables show integration at first order I(1) with no co-integration; otherwise, VECM can be applied in the case of co-integration with the same order of integration [44]. Hence, there is the prerequisite to detecting the order of integration of each variable before selecting VECM or VAR.

We employed two unit roots tests, the Augmented-Dickey-Fuller (ADF) and Philips-Perron (PP) tests, to check the stationarity of each variable of the model. After identifying it, we employed the Johansen co-integration test to analyze the long-run relationship among variables of the model. We employed VECM to detect causality among variables of the model in the long-run and short-run by following the approach adopted by the prior studies of M Belloumi [21], and G Erdal, H Erdal, and K Esengün [49]. Furthermore, we employed the variance decomposition (VDC) test to have more consistent results by following the prior study conducted by S-D Park [62].

We used annual time-series data on FDI in the power and energy sector of Pakistan, energy consumption, and gross domestic product (GDP) for the period 1990-2017. The data were obtained from the State bank of Pakistan (SBP) and World Development Indicators (WDI).

\subsection{Empirical Models}

To find the co-integration and causality among FDI in the power and energy sector, energy consumption, and GDP by using the Johansen co-integration test and VECM, in line with a prior study [12], this study ponders the following equations:

$$
\begin{aligned}
& \Delta \ln F D I_{t}=\sum_{i=1}^{K 11} \alpha_{11 i} \Delta \ln F D I_{t-i}+\sum_{j=1}^{k 12} \alpha_{12 j} \Delta \ln G D P_{t-j}+\sum_{l=1}^{k 13} \alpha_{13 l} \Delta \ln E C_{t-l}+\alpha_{13} E C T_{t-1}+\epsilon_{1 t}+\alpha_{10} \\
& \Delta \ln E C_{t}=\sum_{i=1}^{K 21} \alpha_{21 i} \Delta \ln E C_{t-i}+\sum_{j=1}^{k 22} \alpha_{22 j} \Delta \ln F D I_{t-j}+\sum_{l=1}^{k 23} \alpha_{23 l} \Delta \ln G D P_{t-l}+\alpha_{23} E C T_{t-2}+\epsilon_{2 t}+\alpha_{20} \\
& \Delta \ln G D P_{t}=\sum_{i=1}^{K 31} \alpha_{31 i} \Delta \ln G D P_{t-i}+\sum_{j=1}^{k 32} \alpha_{32 j} \Delta \ln E C_{t-j}+\sum_{l=1}^{k 33} \alpha_{33 l} \Delta \ln F D I_{t-l}+\alpha_{33} E C T_{t-3}+\epsilon_{3 t}+\alpha_{30}
\end{aligned}
$$

In Equations (1) to (3), FDI, EC, and GDP represent foreign direct investment, energy consumption, and gross domestic product, respectively, as a proxy for economic growth. All variables are set into their natural logarithmic form before the empirical analysis. It is helpful to interpret the series in growth terms after considering the first difference. ECT stands for error correction term, which highlights the long-run effect in these variables; ks shows the lag count; and $\Delta \mathrm{s}$ are the difference operators to detect short-run disturbances in these variables. Furthermore, $\in_{1 t}, \in_{2 t}$, and $\in_{3 t}$ are the error terms. The causation of all endogenous variables of the model is interlinked with their lag values and the disequilibrium value of the preceding period. ECTs are usually used to capture the long-run effect in the model. If all of the variables of the model are out of equilibrium, then there is a requirement to adjust the dependent variable to minimize the error. This is generally known as the adjustment of equilibrium error [12].

For the time-series data, it is required to check the stationarity for each series by using unit root tests. If the linear combinations of non-stationary series convert into their stationary form with the 
same order of integration, the co-integration approach is applied [63]. If the variables are co-integrated, VECM can be employed to find the Granger causality among the variables. We adopted the same approach to find the causality among FDI in the PESP, energy consumption, and economic growth as depicted in Figure 6. In this procedure, in Equation (1), GDP (EC) shows Granger causality to FDI if the coefficients of lagged GDP (EC) or the coefficient of the lagged error correction term $E C T_{t-1}$ shows statistical significance. Similarly, in Equation (2), FDI (GDP) shows Granger causality to EC if the coefficients of lagged FDI (GDP) or the coefficient of the lagged error correction term $E C T_{t-2}$ shows statistical significance. Likewise, in Equation (3), EC (FDI) shows Granger causality to GDP if the coefficients of lagged EC (FDI) or the coefficient of the lagged error correction term $E C T_{t-3}$ shows statistical significance.

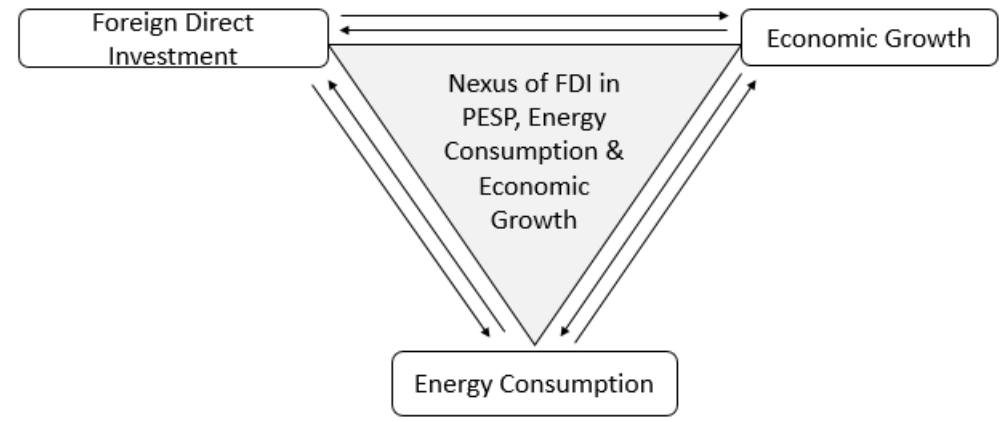

Figure 6. The nexus of FDI in the power and energy sector of Pakistan (PESP), Energy Consumption, and Economic Growth.

\section{Empirical Results}

\subsection{Descriptive Statistics}

Table 3 highlights the descriptive statistics for each variable of the model. The average value of FDI is 490.69 with a standard deviation of 347.24 , which shows the higher variations among the values of FDI. The minimum value for FDI is 80 with the maximum value of 1285.44 . The average value of energy consumption is 465.83 with a standard deviation of 33.58 , which shows less variations among the values. The minimum value for energy consumption is 397.27 with a maximum value of 523.76 . The mean value of GDP is 799.09 with a standard deviation of 385.33, which highlights the higher variations among the values of GDP. The minimum value of GDP is 371.57 with a maximum value of 1547.85 .

Table 3. The Descriptive Statistics.

\begin{tabular}{ccccccc}
\hline Variables & Units & Mean & Median & Minimum & Maximum & Std. Dev. \\
\hline $\begin{array}{c}\text { Foreign Direct } \\
\text { Investment }\end{array}$ & Current USD in Millions & 490.69 & 322.56 & 80.00 & 1285.44 & 347.24 \\
\hline $\begin{array}{c}\text { Energy } \\
\text { Consumption }\end{array}$ & $\begin{array}{c}\text { Kg of Oil equivalent } \\
\text { (Per Capita) }\end{array}$ & 465.83 & 469.24 & 397.27 & 523.76 & 33.58 \\
\hline GDP & $\begin{array}{c}\text { Current USD in Millions } \\
\text { (Per Capita) }\end{array}$ & 799.09 & 606.70 & 371.57 & 1547.85 & 385.33 \\
\hline
\end{tabular}

\subsection{Unit Root Tests}

We checked the stationarity of each variable, including FDI, energy consumption, and GDP, by using the Augmented-Dickey-Fuller (ADF) and Philips-Perron (PP) unit root tests; the results are shown in Tables 4 and 5, respectively. The criteria to decide on a stationary or non-stationary series is dependent on the test statistics and probability values of the variables. The results of both tests-ADF and PP-highlight that all of the variables of the models are non-stationary at the level; however, these variables are converted to be stationary at the first difference with a I(1) order of integration. 
Table 4. The Results of Augmented-Dickey-Fuller (ADF) Unit Root Tests.

\begin{tabular}{|c|c|c|c|c|c|}
\hline \multirow{3}{*}{ Variables } & \multicolumn{4}{|c|}{ Augmented-Dickey-Fuller (ADF) Test } & \multirow{3}{*}{$\begin{array}{c}\text { Order of } \\
\text { Integration }\end{array}$} \\
\hline & \multicolumn{2}{|c|}{ Constant } & \multicolumn{2}{|c|}{ Constant and Trend } & \\
\hline & At Level & $\begin{array}{c}\text { At 1st } \\
\text { Difference }\end{array}$ & At Level & $\begin{array}{c}\text { At 1st } \\
\text { Difference }\end{array}$ & \\
\hline$\triangle \mathrm{LNFDI}$ & $\begin{array}{c}-1.3986 \\
(0.5680)\end{array}$ & $\begin{array}{l}-4.7820 \\
(0.0008)\end{array}$ & $\begin{array}{l}-4.2279 \\
(0.0162)\end{array}$ & $\begin{array}{c}-4.6716 \\
(0.0049)\end{array}$ & $\mathrm{I}(1)$ \\
\hline$\triangle \mathrm{LNEC}$ & $\begin{array}{l}-2.5164 \\
(0.1228)\end{array}$ & $\begin{array}{l}-3.5833 \\
(0.0134)\end{array}$ & $\begin{array}{c}-0.4776 \\
(0.9784)\end{array}$ & $\begin{array}{l}-4.7532 \\
(0.0041)\end{array}$ & $\mathrm{I}(1)$ \\
\hline$\triangle \mathrm{LNGDP}$ & $\begin{array}{c}0.1483 \\
(0.9636)\end{array}$ & $\begin{array}{l}-4.4949 \\
(0.0015)\end{array}$ & $\begin{array}{l}-1.6087 \\
(0.7626)\end{array}$ & $\begin{array}{l}-4.5154 \\
(0.0072)\end{array}$ & $\mathrm{I}(1)$ \\
\hline
\end{tabular}

Note: The corresponding probability values are given in parenthesis.

Table 5. The Results of the Philips-Perron (PP) Unit Root Tests.

\begin{tabular}{|c|c|c|c|c|c|}
\hline \multirow{3}{*}{ Variables } & \multicolumn{4}{|c|}{ Philips-Perron (PP) Test } & \multirow{3}{*}{$\begin{array}{c}\text { Order of } \\
\text { Integration }\end{array}$} \\
\hline & \multicolumn{2}{|c|}{ Constant } & \multicolumn{2}{|c|}{ Constant and Trend } & \\
\hline & At Level & $\begin{array}{c}\text { At 1st } \\
\text { Difference }\end{array}$ & At Level & $\begin{array}{c}\text { At 1st } \\
\text { Difference }\end{array}$ & \\
\hline$\triangle \mathrm{LNFDI}$ & $\begin{array}{l}-1.4154 \\
(0.5598)\end{array}$ & $\begin{array}{l}-4.7771 \\
(0.0008)\end{array}$ & $\begin{array}{l}-2.5017 \\
(0.3247)\end{array}$ & $\begin{array}{l}-4.6541 \\
(0.0051)\end{array}$ & $\mathrm{I}(1)$ \\
\hline$\triangle \mathrm{LNEC}$ & $\begin{array}{l}-2.4232 \\
(0.1451)\end{array}$ & $\begin{array}{l}-3.5833 \\
(0.0134)\end{array}$ & $\begin{array}{l}-0.5413 \\
(0.9746)\end{array}$ & $\begin{array}{l}-4.7524 \\
(0.0041)\end{array}$ & $\mathrm{I}(1)$ \\
\hline$\triangle \mathrm{LNGDP}$ & $\begin{array}{l}0.10918 \\
(0.9605)\end{array}$ & $\begin{array}{l}-4.4826 \\
(0.0016)\end{array}$ & $\begin{array}{l}-1.6087 \\
(0.7626)\end{array}$ & $\begin{array}{c}-4.4992 \\
(0.0073)\end{array}$ & $\mathrm{I}(1)$ \\
\hline
\end{tabular}

Note: The corresponding probability values are given in parenthesis.

\subsection{Johansen Co-Integration and Granger Causality Tests}

Before applying the Granger causality tests, the Johansen Co-integration technique was applied to analyze the co-integration among the variables of the model. The results of this approach are displayed in Table 6. The number of lags is determined by following the Akaike Information Criterion (AIC). On the basis of trace and maximum Eigenvalue tests, the hypothesis of 'none' co-integrating equations in the model is rejected at the $5 \%$ significance level. Hence, it can be extracted that FDI, energy consumption, and GDP have at least one co-integration equation, which highlights the long-run integration among the variables of the model.

Table 6. The Results of the Johansen Co-integration Test.

\begin{tabular}{ccccccccc}
\hline \multirow{2}{*}{$\begin{array}{c}\text { Number of Co-Integration } \\
\text { Equations }\end{array}$} & Eigenvalue & \multicolumn{3}{c}{ Trace Test } & \multicolumn{3}{c}{ Max. Eigenvalue Test } \\
\cline { 3 - 8 } & & $\lambda_{\text {trace }}$ & $\begin{array}{c}\mathbf{5 \%} \text { Critical } \\
\text { Value }\end{array}$ & Prob. & $\lambda_{\text {max }}$ & $\begin{array}{c}\mathbf{5} \% \text { Critical } \\
\text { Value }\end{array}$ & Prob. \\
\hline None ${ }^{* *}$ & 0.586 & 35.69 & 29.80 & 0.009 & 22.896 & 21.132 & 0.028 \\
At most 1 & 0.385 & 12.80 & 15.50 & 0.122 & 12.625 & 14.265 & 0.089 \\
\hline
\end{tabular}

After finding the co-integration among the variables, the VECM was applied to ascertain the sources and specify the directions of causality among FDI in the PESP, energy consumption, and GDP in the long-run and the short-run. The results are shown in Table 7. The decision criteria are dependent on the test statistics, which comprise the values of $t$-tests and Wald tests. The Wald tests were employed to analyze the causality among variables in the form of a group. The results of Wald test- 1 do not show mutual Granger causality of energy consumption and FDI to GDP, $\chi^{2}=3.7613$ 
(0.1525). Furthermore, the results of Wald test- 2 confirm the mutual Granger causality of GDP and FDI to energy consumption, $\chi^{2}=6.6050$ (0.0368). Moreover, the results of Wald test- 3 do not highlight the mutual Granger causality of GDP and energy consumption to FDI, $\chi^{2}=2.8156(0.2447)$.

Table 7. The Results of the Granger Causality Test (VECM).

\begin{tabular}{|c|c|c|c|c|c|c|}
\hline \multirow{3}{*}{$\begin{array}{c}\text { Dependent } \\
\text { Variables }\end{array}$} & \multicolumn{4}{|c|}{ Sources of Causation } & \multirow{3}{*}{$\begin{array}{l}\text { Short-Run } \\
\text { Relationship }\end{array}$} & \multirow{3}{*}{$\begin{array}{l}\text { Long-Run } \\
\text { Relationship }\end{array}$} \\
\hline & \multicolumn{3}{|c|}{ Short-Run Granger Causal Relationship } & \multirow{2}{*}{$\begin{array}{c}\text { Long-Run } \\
\mathrm{ECT}_{t-\mathrm{i}}\end{array}$} & & \\
\hline & $\Delta$ LNFDI & $\triangle \mathrm{LNEC}$ & $\Delta$ LNGDP & & & \\
\hline$\triangle \mathrm{LNFDI}$ & - & $\begin{array}{c}1.3999 \\
(0.2367) \\
\end{array}$ & $\begin{array}{c}0.5704 \\
(0.4501) \\
\end{array}$ & $\begin{array}{c}0.7986 \\
(0.4275) \\
\end{array}$ & No causality & No \\
\hline$\triangle \mathrm{LNEC}$ & $\begin{array}{l}0.00108 \\
(0.9738)\end{array}$ & - & $\begin{array}{l}6.5928^{* *} \\
(0.0102)\end{array}$ & $\begin{array}{c}-4.0363 \text { * } \\
(0.0001)\end{array}$ & $\begin{array}{c}\text { GDP causes } \\
\text { EC }\end{array}$ & Yes \\
\hline$\triangle \mathrm{LNGDP}$ & $\begin{array}{c}1.0448 \\
(0.3067)\end{array}$ & $\begin{array}{c}3.0630^{* * *} \\
(0.0801)\end{array}$ & - & $\begin{array}{c}1.3564 \\
(0.1798)\end{array}$ & $\begin{array}{c}\text { EC causes } \\
\text { GDP }\end{array}$ & No \\
\hline
\end{tabular}

Note: ${ }^{*}{ }^{* *}$, and ${ }^{* * *}$ represent the $1 \%, 5 \%$, and $10 \%$ significance levels, respectively. The corresponding probability values are given in parenthesis.

The results highlight that both GDP and energy consumption do not have a causal relationship with FDI in both the short-run and the long-run. In contrast, positive bi-directional causality is found to run from GDP to energy consumption and from energy consumption to GDP in the short-run at the $5 \%$ and $10 \%$ significance levels, respectively. This predicts that an increase in GDP leads to an increase in energy consumption and vice versa. It can be extracted that the economic growth of Pakistan is dependent on energy consumption, as it plays a vital role in creating economic activity in the country. Our results are consistent with the findings of the previous studies conducted by G Erdal, H Erdal, and K Esengün [49], J Asafu-Adjaye [57], C-C Lee, C-P Chang, and P-F Chen [60], C-C Lee and C-P Chang [64], S Paul and RN Bhattacharya [65], S-H Yoo [66], and J Asafu-Adjaye [57] to find the causality between economic growth and energy consumption in the context of different countries.

Bi-directional causality between GDP and energy consumption is inevitable for Pakistan, which is a rapidly growing developing country. Bi-directional causality has also been found in the case of many emerging countries, such as Turkey and India. Indeed, the economic growth helps to accelerate the energy consumption at the beginning. On the other side, technological development caused by economic growth helps to bring energy sources to the country, which stimulate the economic growth. Because Pakistan is highly dependent on external energy sources, any hurdle in the way of energy supply could disrupt the energy consumption. As a result, the overall economic development of the country could be adversely affected.

Furthermore, the coefficient of $E C T_{t-1}$ is found to be insignificant, which indicates that a long-run equilibrium relationship does not exist from GDP and energy consumption to FDI in Equation (1). The coefficient of $E C T_{t-2}$ is found to be significant at the $1 \%$ level of significance in Equation (2); so, it confirms the presence of a negative long-run equilibrium relationship from FDI and GDP to energy consumption. This result is similar to the findings of the previous study conducted by F Khatun and $M$ Ahamad [12], which found a negative long-run equilibrium relationship from FDI and GDP to energy consumption in the context of Bangladesh. As we have mentioned earlier, Pakistan is facing the problem of circular debt and receiving a large amount of FDI, which consists mainly of loans. If Pakistan could not pay back these loans in the future, then the economy of Pakistan is likely to be negatively affected by yet more accumulated debt. Eventually, the energy consumption could be adversely affected in the long-run. The coefficient of $E C T_{t-3}$ is found to be insignificant, which highlights that a long-run equilibrium relationship does not exist from FDI and energy consumption to GDP in Equation (3).

In addition, Table 8 highlights the results of the variance decomposition test. The results demonstrate that GDP shows a strong self-explanatory power in the short-run, while it is decreased to 
$91 \%$ in the long-run. The other two variables, FDI and energy consumption, do not show shocks to the GDP in the short-run. Moreover, $94 \%$ of FDI is explained by shocks to the FDI in the short-run. This self-explanatory power of FDI is decreased to $89 \%$ in the long-run. In the short-run, GDP accounts for $6 \%$ of FDI, while FDI is affected by the energy consumption in the long-run. Furthermore, energy consumption shows a self-explanatory power of $82 \%$ and $24 \%$ in the short-run and long-run, respectively. In the short-run, $0.25 \%$ of FDI is explained by shocks to energy consumption and increases over time, followed by GDP. These findings suggest that energy consumption is highly affected by economic growth in the short-run.

Table 8. The Results of the Variance Decomposition Test.

\begin{tabular}{cccccccccccc}
\hline \multicolumn{3}{c}{ Variance Decomposition of LNGDP } & \multicolumn{3}{c}{ Variance Decomposition of LNFDI } & \multicolumn{3}{c}{ Variance Decomposition of LNEC } \\
\hline Period & LNGDP & LNFDI & LNEC & Period & LNGDP & LNFDI & LNEC & Period & LNGDP & LNFDI & LNEC \\
\hline 1 & 100.000 & 0.0000 & 0.0000 & 1 & 5.9930 & 94.0070 & 0.0000 & 1 & 17.5759 & 0.2483 & 82.1758 \\
2 & 95.0154 & 0.5998 & 4.3848 & 2 & 2.9564 & 94.8890 & 2.1546 & 2 & 30.2690 & 5.8008 & 63.9302 \\
3 & 94.1765 & 0.6920 & 5.1314 & 3 & 2.9420 & 93.3473 & 3.7106 & 3 & 25.4088 & 16.3689 & 58.2224 \\
4 & 93.0484 & 0.8583 & 6.0933 & 4 & 3.3556 & 91.7630 & 4.8813 & 4 & 21.2041 & 27.1569 & 51.6390 \\
5 & 92.5040 & 0.9614 & 6.5346 & 5 & 3.7874 & 90.5917 & 5.6209 & 5 & 16.7429 & 37.6393 & 45.6178 \\
6 & 92.0632 & 1.0592 & 6.8777 & 6 & 4.0831 & 89.8014 & 6.1155 & 6 & 13.2055 & 46.8122 & 39.9824 \\
7 & 91.7666 & 1.1398 & 7.0936 & 7 & 4.2783 & 89.2817 & 6.4400 & 7 & 10.5498 & 54.4693 & 34.9809 \\
8 & 91.5337 & 1.2124 & 7.2540 & 8 & 4.3952 & 88.9452 & 6.6596 & 8 & 8.6843 & 60.6554 & 30.6603 \\
9 & 91.3544 & 1.2764 & 7.3692 & 9 & 4.4615 & 88.7297 & 6.8088 & 9 & 7.4308 & 65.5681 & 27.0011 \\
10 & 91.2087 & 1.3340 & 7.4573 & 10 & 4.4938 & 88.5943 & 6.9118 & 10 & 6.6233 & 69.4453 & 23.9314 \\
\hline
\end{tabular}

\section{Conclusions and Policy Implications}

This study highlighted the present situation of the PESP and empirically analyzed the causality among the FDI in the power and energy sector, the energy consumption, and the economic growth of Pakistan for the period 1990-2017. We employed ADF and PP unit root tests to check the stationarity of each variable. The results of these tests highlight that all of the variables of the models are non-stationary at the level; however, these variables are converted to be stationary at the first difference with a I(1) order of integration. After converting the variables into their stationary form, we employed the Johansen co-integration technique and a Granger causality test (VECM) to find the causality among variables in the long-run and short-run. Moreover, we employed the variance decomposition (VDC) test to yield more consistent results.

The sector-wise comparison of FDI reveals that the PESP has received a relatively higher amount of FDI than other sectors of the economy in recent years. Furthermore, the trends in energy production and energy usage reveal a substantial gap in previous years. The empirical results of the study confirmed the presence of a positive bi-directional causal relationship between energy consumption and economic growth. It refutes the assumption of neoclassical theory that energy is unbiased to growth. It also indicates that the declining trend in energy consumption could be harmful to economic growth and vice versa. Therefore, policy-makers should formulate policies to ensure the availability of energy and efficient energy usage for the production of goods and services.

Furthermore, the results of the study highlight that there is a negative long-run equilibrium relationship between FDI and GDP with energy consumption. Presently, the power and energy sector of Pakistan (PESP) is facing a severe problem of circular debt while also receiving loan-based investments to meet its needs. If Pakistan could not pay back its loans in the future, the economy of Pakistan is likely to be negatively affected by yet more accumulated debt. Ultimately, the energy consumption could be adversely affected. We suggest that the GOP should attain the minimum debt level and discourage loan-based investments. They should find alternative investment sources (without loans) and also formulate policies to increase the tax collection and export level.

Moreover, the GOP should make serious efforts to deal with the major constraints on the power and energy sector, such as intense reliance on oil and gas, de-rated capacity, circular debt, energy security and threats, and bad governance. It should adopt alternative, and less costly, energy sources 
to decrease the intense reliance on oil and gas. The de-rated capacity of energy units could be better by investing more funds to overhaul the energy units. The problem of circular debt could be fixed by real investment (without loans), effective management, and control over the cash flows. It is necessary to take effective security measures in remote areas to exercise control over energy security problems. Better governance, by hiring productive staff and controlling the corruption factor, could be beneficial to improve the performance of Pakistan's power and energy sector.

Author Contributions: Conceptualized, drafted methodology, data collected \& analyzed, and wrote-original manuscript, R.L.; reviewed and supervised this study, L.L.

Funding: The APC was funded by Nanjing Agricultural University, China.

Acknowledgments: The authors would like to acknowledge the financial support provided by Nanjing Agricultural University, China. Furthermore, we acknowledge the comments and suggestions given by anonymous reviewers that have significantly improved the quality of our work, and the overall support of Nadeem Khan from Nanjing Agricultural University, China to complete this study.

Conflicts of Interest: The authors declare that the research was conducted in the absence of any commercial or financial relationships that could be construed as a potential conflict of interest.

$\begin{array}{ll}\text { Abbreviations } \\ \text { ADF } & \text { Augmented-Dickey Fuller } \\ \text { AIC } & \text { Akaike Information Criterion } \\ \text { ARDL } & \text { Autoregressive Distributed Lag } \\ \text { CPEC } & \text { China Pakistan Economic Corridor } \\ \text { CPPA } & \text { Central Power Purchase Agency } \\ \text { DISCOS } & \text { Distribution Companies } \\ \text { ECT } & \text { Error Correction term } \\ \text { FDI } & \text { Foreign Direct Investment } \\ \text { GDP } & \text { Gross Domestic Product } \\ \text { GENCOS } & \text { Generation Companies } \\ \text { GMM } & \text { Generalized Method of Moments } \\ \text { GOP } & \text { Government of Pakistan } \\ \text { IPPs } & \text { Independent Power Producers } \\ \text { KESC } & \text { Karachi Electric Supply Corporation } \\ \text { LNG } & \text { Liquefied Natural Gas } \\ \text { NTDC } & \text { National Transmission \& Dispatch Company } \\ \text { OGDCL } & \text { Oil and Gas Development Company Limited } \\ \text { PAEC } & \text { Pakistan Atomic Energy Commission } \\ \text { PARCO } & \text { Pak Arab Refinery Limited } \\ \text { PESP } & \text { Power and Energy Sector of Pakistan } \\ \text { PHPL } & \text { Power Holding Private Limited } \\ \text { POL } & \text { Pakistan Oilfields Limited } \\ \text { PP } & \text { Philips-Perron } \\ \text { PPL } & \text { Pakistan Petroleum Limited } \\ \text { PRL } & \text { Pakistan Refinery Limited } \\ \text { PSO } & \text { Pakistan State Oil } \\ \text { SAARC } & \text { South Asian Association for Regional Cooperation } \\ \text { SNGPL } & \text { Sui Northern Gas Pipelines Limited } \\ \text { SSGCL } & \text { Sui Southern Gas Company Limited } \\ \text { VAR } & \text { Vector Auto Regression } \\ \text { VECM } & \text { Vector Error Correction Model } \\ \text { WAPDA } & \end{array}$




\section{References}

1. Latief, R.; Lefen, L. The effect of exchange rate volatility on international trade and foreign direct investment (FDI) in developing countries along "one belt and one road". Int. J. Financ. Stud. 2018, 6, 86. [CrossRef]

2. Government of Pakistan (GOP). Pakistan Economic Survey 2017-2018; Minsitry of Finance, Government of Pakistan: Islamabad, Pakistan, 2018.

3. Shahbaz, M.; Lean, H.H. Does financial development increase energy consumption? The role of industrialization and urbanization in tunisia. Energy Policy 2012, 40, 473-479. [CrossRef]

4. Mahmood, A.; Javaid, N.; Zafar, A.; Riaz, R.A.; Ahmed, S.; Razzaq, S. Pakistan's overall energy potential assessment, comparison of lng, tapi and ipi gas projects. Renew. Sustain. Energy Rev. 2014, 31, 182-193. [CrossRef]

5. Rafique, M.M.; Rehman, S. National energy scenario of pakistan-current status, future alternatives, and institutional infrastructure: An overview. Renew. Sustain. Energy Rev. 2017, 69, 156-167. [CrossRef]

6. Ali, S.S.; Badar, S. Dynamics of circular debt in pakistan and its resolution. Lahore J. Econ. 2010, 15, 61-74.

7. State Bank of Pakistan (SBP). State Bank of Pakistan Annual Report 2012-2013; State Bank of Pakistan: Karachi, Pakistan, 2013.

8. NTDC. Power System Statistics 2013-2014; National Transmission and Despatch Company: Lahore, Pakistan, 2014.

9. Mustafa, K. Rs977 Billion Circular Debt Makes Power Sector Unsustainable. Available online: https:/ / www. thenews.com.pk/print/292960-rs977-billion-circular-debt-makes-power-sector-unsustainable (accessed on 16 March 2018).

10. Bhutta, Z. Power production rises 30\% over five years. The Express Tribune, 22 July $2018 ; 1$.

11. SBP. Foreign Investment in Pakistan-by Country; State Bank of Pakistan: Karachi, Pakistan, 2018.

12. Khatun, F.; Ahamad, M. Foreign direct investment in the energy and power sector in bangladesh: Implications for economic growth. Renew. Sustain. Energy Rev. 2015, 52, 1369-1377. [CrossRef]

13. Adams, S. Foreign direct investment, domestic investment, and economic growth in sub-saharan Africa. J. Policy Model. 2009, 31, 939-949. [CrossRef]

14. Balasubramanyam, V.N.; Salisu, M.; Sapsford, D. Foreign direct investment and growth in EP and is countries. Econ. J. 1996, 106, 92-105. [CrossRef]

15. O'Hearn, D. Tncs, intervening mechanisms and economic growth in ireland: A longitudinal test and extension of the bornschier model. World Dev. 1990, 18, 417-429. [CrossRef]

16. Bornschier, V. Multinational corporations and economic growth: A cross-national test of the decapitalization thesis. J. Dev. Econ. 1980, 7, 191-210. [CrossRef]

17. Stoneman, C. Foreign capital and economic growth. World Dev. 1975, 3, 11-26. [CrossRef]

18. Herzer, D. How does foreign direct investment really affect developing countries' growth? Rev. Int. Econ. 2012, 20, 396-414. [CrossRef]

19. Almfraji, M.A.; Almsafir, M.K.; Liu, Y. Economic growth and foreign direct investment inflows: The case of qatar. Procedia Soc. Behav. Sci. 2014, 109, 1040-1045. [CrossRef]

20. Zhao, C.; Du, J. Causality between fdi and economic growth in China. Chin. Econ. 2007, 40, 68-82. [CrossRef]

21. Belloumi, M. Energy consumption and gdp in tunisia: Cointegration and causality analysis. Energy Policy 2009, 37, 2745-2753. [CrossRef]

22. Hao, Y.; Zhu, L.; Ye, M. The dynamic relationship between energy consumption, investment and economic growth in China's rural area: New evidence based on provincial panel data. Energy 2018, 154, 374-382. [CrossRef]

23. Mah, J.S. Foreign direct investment inflows and economic growth of China. J. Policy Model. 2010, 32, $155-158$. [CrossRef]

24. Fadhil, M.A.; Almsafir, M.K. The role of fdi inflows in economic growth in malaysia (time series: 1975-2010). Procedia Econ. Financ. 2015, 23, 1558-1566. [CrossRef]

25. Chakraborty, C.; Nunnenkamp, P. Economic reforms, fdi, and economic growth in India: A sector level analysis. World Dev. 2008, 36, 1192-1212. [CrossRef]

26. Anwar, S.; Sun, S. Financial development, foreign investment and economic growth in Malaysia. J. Asian Econ. 2011, 22, 335-342. [CrossRef] 
27. Tang, C.F.; Tan, B.W. The linkages among energy consumption, economic growth, relative price, foreign direct investment, and financial development in Malaysia. Qual. Quant. 2014, 48, 781-797. [CrossRef]

28. Gupta, P.; Singh, A. Causal nexus between foreign direct investment and economic growth: A study of brics nations using vecm and granger causality test. J. Adv. Manag. Res. 2016, 13, 179-202. [CrossRef]

29. Iamsiraroj, S. The foreign direct investment-economic growth nexus. Int. Rev. Econ. Financ. 2016, 42, 116-133. [CrossRef]

30. Omri, A.; Kahouli, B. Causal relationships between energy consumption, foreign direct investment and economic growth: Fresh evidence from dynamic simultaneous-equations models. Energy Policy 2014, 67, 913-922. [CrossRef]

31. Agrawal, G. Foreign direct investment and economic growth in brics economies: A panel data analysis. J. Econ. Bus. Manag. 2015, 3, 421-424. [CrossRef]

32. Srinivasan, P.; Kalaivani, M.; Ibrahim, P. An empirical investigation of foreign direct investment and economic growth in SAARC nations. J. Asia Business Stud. 2011, 5, 232-248. [CrossRef]

33. Al-Iriani, M. Foreign direct investment and economic growth in the GCC countries: A causality investigation using heterogeneous panel analysis. Top. Middle East. N. Afr. Econ. 2007, 9, 3-32.

34. Gui-Diby, S.L. Impact of foreign direct investments on economic growth in Africa: Evidence from three decades of panel data analyses. Res. Econ. 2014, 68, 248-256. [CrossRef]

35. Belloumi, M. The relationship between trade, fdi and economic growth in Tunisia: An application of the autoregressive distributed lag model. Econ. Syst. 2014, 38, 269-287. [CrossRef]

36. Kraft, J.; Kraft, A. On the relationship between energy and GNP. J. Energy Dev. 1978, 3, 401-403.

37. Komal, R.; Abbas, F. Linking financial development, economic growth and energy consumption in pakistan. Renew. Sustain. Energy Rev. 2015, 44, 211-220. [CrossRef]

38. Berndt, E.R. Energy Price Increases and the Productivity Slowdown in United States Manufacturing; University of British Columbia, Department of Economics: Vancouver, BC, Canada, 1980.

39. Denison, E.F. Explanations of Declining Productivity Growth; Brookings Institution: Washington, DC, USA, 1979; Volume 354.

40. Ayres, R.U.; Nair, I. Thermodynamics and economics. Phys. Today 1984, 37, 62-71. [CrossRef]

41. Cleveland, C.J.; Costanza, R.; Hall, C.A.; Kaufmann, R. Energy and the US economy: A biophysical perspective. Science 1984, 225, 890-897. [CrossRef] [PubMed]

42. Stern, D.I. Limits to substitution and irreversibility in production and consumption: A neoclassical interpretation of ecological economics. Ecol. Econ. 1997, 21, 197-215. [CrossRef]

43. Ozturk, I.; Acaravci, A. $\mathrm{CO}_{2}$ emissions, energy consumption and economic growth in turkey. Renew. Sustain. Energy Rev. 2010, 14, 3220-3225. [CrossRef]

44. Zhang, X.-P.; Cheng, X.-M. Energy consumption, carbon emissions, and economic growth in China. Ecol. Econ. 2009, 68, 2706-2712. [CrossRef]

45. Bowden, N.; Payne, J.E. The causal relationship between US energy consumption and real output: A disaggregated analysis. J. Policy Model. 2009, 31, 180-188. [CrossRef]

46. Shahbaz, M.; Zeshan, M.; Afza, T. Is energy consumption effective to spur economic growth in pakistan? New evidence from bounds test to level relationships and granger causality tests. Econ. Model. 2012, 29, 2310-2319. [CrossRef]

47. Alshehry, A.S.; Belloumi, M. Energy consumption, carbon dioxide emissions and economic growth: The case of Saudi Arabia. Renew. Sustain. Energy Rev. 2015, 41, 237-247. [CrossRef]

48. Oh, W.; Lee, K. Causal relationship between energy consumption and gdp revisited: The case of Korea 1970-1999. Energy Econ. 2004, 26, 51-59. [CrossRef]

49. Erdal, G.; Erdal, H.; Esengün, K. The causality between energy consumption and economic growth in Turkey. Energy Policy 2008, 36, 3838-3842. [CrossRef]

50. Karanfil, F. How many times again will we examine the energy-income nexus using a limited range of traditional econometric tools? Energy Policy 2009, 37, 1191-1194. [CrossRef]

51. Lise, W.; Van Montfort, K. Energy consumption and gdp in turkey: Is there a co-integration relationship? Energy Econ. 2007, 29, 1166-1178. [CrossRef]

52. Bakhsh, K.; Rose, S.; Ali, M.F.; Ahmad, N.; Shahbaz, M. Economic growth, $\mathrm{CO}_{2}$ emissions, renewable waste and FDI relation in Pakistan: New evidences from 3SLS. J. Environ. Manag. 2017, 196, 627-632. [CrossRef] [PubMed] 
53. Govindaraju, V.C.; Tang, C.F. The dynamic links between $\mathrm{CO}_{2}$ emissions, economic growth and coal consumption in china and india. Appl. Energy 2013, 104, 310-318. [CrossRef]

54. Lau, E.; Chye, X.-H.; Choong, C.-K. Energy-growth causality: Asian countries revisited. Int. J. Energy Econ. Policy 2011, 1, 140-149.

55. Pradhan, R.P.P. Energy consumption-growth nexus in SAARC countries: Using cointegration and error correction model. Mod. Appl. Sci. 2010, 4, 74. [CrossRef]

56. Apergis, N.; Payne, J.E. Energy consumption and economic growth in Central America: Evidence from a panel cointegration and error correction model. Energy Econ. 2009, 31, 211-216. [CrossRef]

57. Asafu-Adjaye, J. The relationship between energy consumption, energy prices and economic growth: Time series evidence from asian developing countries. Energy Econ. 2000, 22, 615-625. [CrossRef]

58. Masih, A.M.; Masih, R. Energy consumption, real income and temporal causality: Results from a multi-country study based on cointegration and error-correction modelling techniques. Energy Econ. 1996, 18, 165-183. [CrossRef]

59. Noor, S.; Siddiqi, M. Energy consumption and economic growth in south asian countries: A co-integrated panel analysis. Int. J. Hum. Soc. Sci. 2010, 5, 921-926.

60. Lee, C.-C.; Chang, C.-P.; Chen, P.-F. Energy-income causality in oecd countries revisited: The key role of capital stock. Energy Econ. 2008, 30, 2359-2373. [CrossRef]

61. Huang, B.-N.; Hwang, M.J.; Yang, C.W. Causal relationship between energy consumption and gdp growth revisited: A dynamic panel data approach. Ecol. Econ. 2008, 67, 41-54. [CrossRef]

62. Park, S.-D. The nexus of FDI, R\&D, and human capital on chinese sustainable development: Evidence from a two-step approach. Sustainability 2018, 10, 2063.

63. Johansen, S.; Juselius, K. Maximum likelihood estimation and inference on cointegration-With applications to the demand for money. Oxf. Bull. Econ. Stat. 1990, 52, 169-210. [CrossRef]

64. Lee, C.-C.; Chang, C.-P. Energy consumption and gdp revisited: A panel analysis of developed and developing countries. Energy Econ. 2007, 29, 1206-1223. [CrossRef]

65. Paul, S.; Bhattacharya, R.N. Causality between energy consumption and economic growth in india: A note on conflicting results. Energy Econ. 2004, 26, 977-983. [CrossRef]

66. Yoo, S.-H. The causal relationship between electricity consumption and economic growth in the asean countries. Energy Policy 2006, 34, 3573-3582. [CrossRef] 